UJBM, Vol. 7, No. 2, July - December 2008, pp 42-52

ISSN 0975-3311 | https://doi.org/10.12725/ujbm.13.4

\title{
A STUDY ON CUSTOMER SATISFACTION TOWARDS CELL PHONE WITH SPECIAL REFERENCE TO NOKIA AT NAMAKKAL DISTRICT
}

\author{
R. Eswaran*
}

\section{ABSTRACT}

In our day today life telecommunication is the most important media for communication. It makes our job easier. This type of communication is very cheaper and also it saves our time. Information can be transferred easily and quickly through this media than other Medias. This kind of communication made people to feel the whole world come in to their hands. They feel to be closer even though, they are separated by long distance. Telecommunication is the mode of simplest communication, which enables us to command, order and share the information with apt time.

One of the main reasons for Nokia's success in India has been its marketing strategy. Adapting its products to the needs of customers, the

* Reader \& Head, Department of commerce, KSR College of Arts and Science, Tiruchengode. (TK) - 637 215. Namakkal (DT). Tamil Nadu. Email: Eswaran1971@rediffmail.com, Mobile: 9994898590 . 
company went in for an India-specific strategy, which included launching new products and enhancing the products with features designed specifically for local customers, as well as promotional campaigns targeted at the Indian audience to gain a foothold in the market. The company developed an extensive distribution network to take its products to the rural markets of India.

\section{Introduction}

Today, communication is one of the gifts of man. It acts as a repository of wisdom, a propeller for the advancement of knowledge and a telescope to view the vision of the future. Communication is the life blood of business.

In our day today life telecommunication is the most important media for communication. It makes our job easier. This type of communication is very cheaper and also it saves our time. Information can be transferred easily and quickly through this media than other medias. This kind of communication made people to feel the whole world come in to their hands. They feel to be closer even though, they are separated by long distance. Telecommunication is the mode of simplest communication, which enables us to command, order and share the information with apt time.

In olden days marketers had close and direct contact with the consumers which enabled them to understand consumers. But the growth in the size and firms of markets has made it impossible on the part of the marketers to have such a close contact. This necessitates the present day marketing managers to conduct consumer research to have an idea about the behaviors of consumers.

\section{History of Cellular Phone}

1947 was a big year for what was to become the cell phone industry. In that year researchers first developed ideas as to the possibility of creating mobile phones that used "cells" that would identify a user in whatever specific region he or she was initiating the call from. However, since technology was fairly limited at the time, more development was required. 


\section{Introduction of Phones to Public}

The year 1988 changed many of the technologies that had become standard in the past. The Cellular Technology Industry Association was created to set realistic goals for cellular phone providers and research new applications for cell phone development. A new standard was set by the Telecommunications Industry Association with the creation of the TDMA Interim Standard 54, in 1991. Since then, three new technologies have evolved into industry standards for cell phone telecommunications: TDMA IS-136, CDMA IS-95 and GSM.

\section{NOKIA HANDSETS MARKER SHARES IN INDIA}

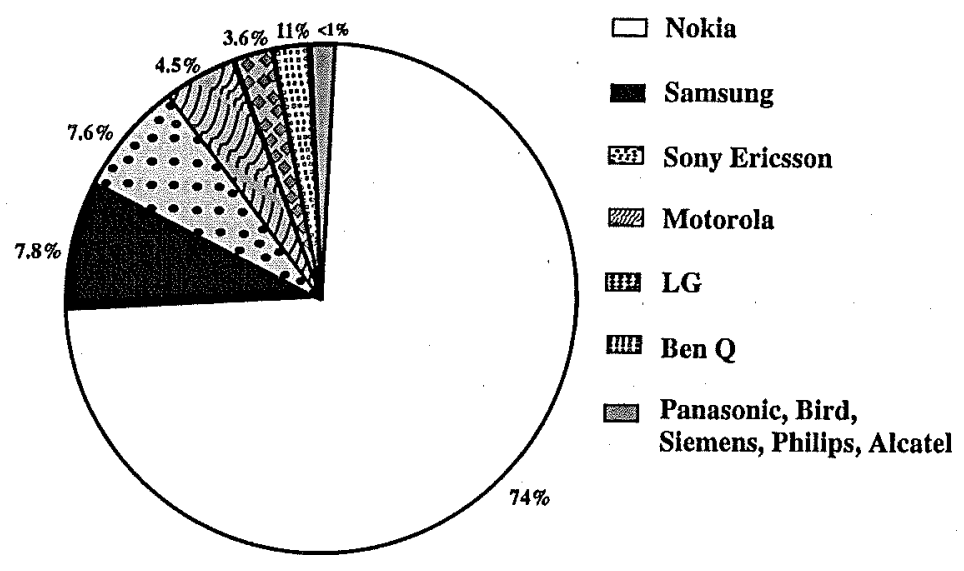

\section{Objectives of the Study:}

1. To find the customer's satisfaction towards the price of Nokia cell phone.

2. To Study the customers' perception towards quality and facilities offered by Nokia cell phone.

3. To identify factors influencing the purchase of Nokia Cell phone. 
4. To know the awareness of customer after the sales service provided by Nokia Cell phone.

5. To suggest improvement to be made in Nokia cell phone

\section{Scope of the Study}

The study will highlight the satisfaction of customers towards Nokia cell phone The study gives some valuable information to Nokia Company that they can improve accordingly, to satisfy customers and serve them better.The study tries to know the views of the customer regarding price, facilities, quality and after sales service provided by Nokia.

\section{Methodology}

The success of any research depends on the systematic method of collecting the data and analyzing the same in a orderly manner. In the present study, an extensive use of primary data was made.

\section{Sampling Design}

For collecting primary data, field survey technique was employed in the study area. In Primary data, satisfaction in price, quality, and facilities offered by Nokia, factors influencing purchase of Nokia cell phone and awareness of customers after sales service provided by Nokia are collected from the respondents. 150 sample respondents were selected for sample survey.

Namakkal District consists of several groups of people. The respondents were chosen from all the groups. Respondents were grouped into 5 categories. They are students, private employees, Government employees, Business people and the fifth category include both housewife and others. In regard to selection of sample respondents 30 Nokia handset users have been selected from respective categories on the basis of convenient sampling technique which arrive to the total of 150 respondents. 
Table 1: Group Distribution of Respondents in the Study Area

\begin{tabular}{|c|l|c|}
\hline S.No. & \multicolumn{1}{|c|}{ Name of the Group } & Total no. of respondents \\
\hline 1 & Students & 30 \\
2 & Private employees & 30 \\
3 & Govt. employees & 30 \\
4 & Business people & 30 \\
5 & House wife \& Others & 30 \\
\hline
\end{tabular}

Table 2: Data Analysis \& Interpresasion Satisfaction Level with Respect to Price

\begin{tabular}{|c|l|c|c|}
\hline S.No. & \multicolumn{1}{|c|}{ Opinion } & No. of Respondents & Percentage \\
\hline 1. & Fully satisfied & 74 & 49 \\
2. & Satisfied & 66 & 44 \\
3. & Dissatisfied & 7 & 5 \\
4. & Highly dissatisfied & 3 & 2 \\
\hline & Total & 150 & 100 \\
\hline
\end{tabular}

Source - Primary data

It is concluded from the analysis that maximum of the respondents are fully satisfied with the price.

Table 3: Product Design of Handset

\begin{tabular}{|c|l|c|c|}
\hline S.No. & \multicolumn{1}{|c|}{ Opinion } & No. of Respondents & Percentage \\
\hline 1. & Fully satisfied & 91 & 61 \\
2. & Moderately satisfied & 58 & 38 \\
3. & Not satisfied & 1 & 1 \\
4. & Dissatisfied & 0 & 0 \\
\hline & Total & 150 & 100 \\
\hline
\end{tabular}

Source - Primary data

It is known from the analysis that maximum of the respondents are fully satisfied with design of Nokia handset. 
Table 4: Opinion About the Performance Level

\begin{tabular}{|c|l|c|c|}
\hline S.No. & \multicolumn{1}{|c|}{ Opinion } & No. of Respondents & Percentage \\
\hline 1. & Excellent & 50 & 33 \\
2. & Good & 85 & 57 \\
3. & Better & 14 & 9 \\
4. & Poor & 1 & 1 \\
\hline & Total & 150 & 100 \\
\hline
\end{tabular}

Source - Primary data

It is concluded from the analysis that maximum of the respondents' opinion is that the performance of Nokia handset is good.

Table 5: Satisfaction Level With Respect to Quality Reception

\begin{tabular}{|c|c|c|c|c|c|c|}
\hline $\begin{array}{l}\text { Sl. } \\
\text { No. }\end{array}$ & Opinion & $\begin{array}{l}\text { Fully } \\
\text { satisfied }\end{array}$ & $\begin{array}{l}\text { Moderately } \\
\text { Satisfied }\end{array}$ & Satisfied & Dissatisfied & $\begin{array}{c}\text { Highly } \\
\text { dissatisfied }\end{array}$ \\
\hline 1. & Ringing tone & $\begin{array}{r}87 \\
(58.0)\end{array}$ & $\begin{array}{r}26 \\
(17.3)\end{array}$ & $\begin{array}{r}29 \\
(19.3)\end{array}$ & $\begin{array}{r}7 \\
(4.7)\end{array}$ & $\begin{array}{r}1 \\
(0.7)\end{array}$ \\
\hline 2. & Display & $\begin{array}{r}68 \\
(45.3)\end{array}$ & $\begin{array}{r}32 \\
(21.3)\end{array}$ & $\begin{array}{r}43 \\
(28.7)\end{array}$ & $\begin{array}{r}7 \\
(4.7)\end{array}$ & \\
\hline 3. & Key pad operation & $\begin{array}{r}\text { 1s } 81 \\
(54.0)\end{array}$ & $\begin{array}{r}21 \\
(14.0)\end{array}$ & $\begin{array}{r}45 \\
(30.0)\end{array}$ & $\begin{array}{r}3 \\
(2.0)\end{array}$ & \\
\hline 4. & Weight & $\begin{array}{r}54 \\
(36.0)\end{array}$ & $\begin{array}{r}27 \\
(18.0)\end{array}$ & $\begin{array}{r}52 \\
(34.7)\end{array}$ & $\begin{array}{r}11 \\
(7.3)\end{array}$ & $\begin{array}{r}6 \\
(4.0)\end{array}$ \\
\hline 5. & Body colour & $\begin{array}{r}67 \\
(44.7)\end{array}$ & $\begin{array}{r}29 \\
(19.3)\end{array}$ & $\begin{array}{r}42 \\
(28.0)\end{array}$ & $\begin{array}{r}6 \\
(4.0)\end{array}$ & $\begin{array}{r}6 \\
(4.0)\end{array}$ \\
\hline 6. & Loud speaker & $\begin{array}{r}63 \\
(42.0)\end{array}$ & $\begin{array}{r}31 \\
(20.7)\end{array}$ & $\begin{array}{r}40 \\
(26.7)\end{array}$ & $\begin{array}{r}8 \\
(5.3)\end{array}$ & $\begin{array}{r}8 \\
(5.3)\end{array}$ \\
\hline
\end{tabular}

Source - Primary data

It is known from the analysis that maximum of the respondents are fully satisfied with design of Nokia handset. 
It is understood from the above table that as follows:

- Most (58\%) of the respondents are fully satisfied with ringing tone.

- Maximum (45.3\%) of the respondents are fully satisfied with display.

- Majority (54\%) of the respondents are fully satisfied with key pad operations.

- Most (36\%) of the respondents are fully satisfied with weight.

- Maximum (44.7\%) of the respondents are fully satisfied with body colour.

- Most (42\%) of the respondents are fully satisfied with loud speaker.

Table 6: Satisfaction Level with Respect to Warranty Period

\begin{tabular}{|c|l|c|c|}
\hline S.No. & \multicolumn{1}{|c|}{ Opinion } & No. of Respondents & Percentage \\
\hline 1. & Fully satisfied & 53 & 35 \\
2. & Moderately satisfied & 71 & 48 \\
3. & Not satisfied & 24 & 16 \\
4. & Dissatisfied & 2 & 1 \\
\hline & Total & 150 & 100 \\
\hline
\end{tabular}

Source - Primary data

It is concluded from the analysis that maximum of the respondents are satisfied with warranty period.

Table 7: Opinion About After Sales Service

\begin{tabular}{|c|l|c|c|}
\hline S.No. & \multicolumn{1}{|c|}{ Opinion } & No. of Respondents & Percentage \\
\hline 1. & Fully satisfied & 33 & 22 \\
2. & Moderately satisfied & 97 & 64 \\
3. & Dissatisfied & 10 & 7 \\
4. & Highly dissatisfied & 10 & 7 \\
\hline & Total & 150 & 100 \\
\hline
\end{tabular}

Source - Primary data

It is concluded from the analysis that maximum of the respondents are moderately satisfied with after sales service. 
Table 8: Factor Influencing Purchase of Nokia

\begin{tabular}{|c|l|c|c|}
\hline S.No. & \multicolumn{1}{|c|}{ Opinion } & No. of Respondents & Percentage \\
\hline 1. & Style & 23 & 15 \\
2. & Color & 8 & 5 \\
3. & Weight & 5 & 4 \\
4. & Facilities & 23 & 15 \\
5. & Durability \& Quality & 31 & 21 \\
6. & Price & 7 & 5 \\
7. & Guaranty / Warranty & 3 & 2 \\
8. & All of the above & 50 & 33 \\
\hline & Total & 150 & 100 \\
\hline
\end{tabular}

Source - Primary data

It is concluded from the analysis that maximum of the respondents are influenced to purchase the Nokia handset for all the factor like style, durability, quality and etc.

Table 9: Opinion About Switchover the Brand in Future

\begin{tabular}{|c|l|c|c|}
\hline S. No. & \multicolumn{1}{|c|}{ Brand } & No. of Respondents & Percentage \\
\hline 1. & Sony Ericsson & 18 & 12 \\
2. & Motorola & 5 & 3 \\
3. & Reliance & 3 & 2 \\
4. & LG & 9 & 6 \\
5. & Panasonic & 1 & 1 \\
6. & Samsung & 10 & 7 \\
7. & Spice & 0 & 0 \\
8. & BPL & 1 & 1 \\
9. & Nokia & 103 & 68 \\
\hline & Total & 150 & 100 \\
\hline
\end{tabular}

Source - Primary data

It is concluded from the analysis that maximum of the respondents are interested to switch to the brand of 'Nokia' again because of its new technology and easy to handle. 


\section{FINDINGS}

- It is found from the analysis that maximum of the respondents are fully satisfied with the price.

- It is inferred from the analysis that maximum of the respondents are fully satisfied with the design of Nokia handset.

- It is known from the analysis the respondents are satisfied with performance level.

- It is found from the analysis that maximum of the respondents have experience the best quality of service provided by Nokia.

- It is inferred from the analysis that maximum of the respondents are satisfied with warranty period.

- It is concluded from the analysis that maximum of the respondents are moderately satisfied with after sales service

- It is inferred from the analysis that maximum of the respondents are influenced to purchase the Nokia handset for all the factors like style, color, weight, durability, quality and etc.

- It is known from the analysis that maximum of the respondents are interested not to switchover the brand of 'Nokia' again because of its new technology and easy to handle.

\section{SUGGESTIONS}

- It is found from the study that the awareness about cellular handset is created more by advertisements, particularly TV advertisements. Hence it is recommended that effective advertising through appropriate media which might be changed from time to time to attract more customers for their business. The advertising strategy shall also be designed that it covers many aspects like presentation, styles, slogan etc.

- It was analyzed from the study that only a considerable percentage of variation was there in preferring the brand. So it reveals that there is a tight competition among the competitors. Hence it is recommended that each competitor must take appropriate steps to attract the consumers by providing various features. 
- The study reveals that considerable percentage of respondents decide to change the models and are awaiting for still more features in the models. Hence the companies can introduce many schemes that will make the customers stay back with the same brand.

- According to the study the degree of influence regarding the price, popularity, size, weight, and quality seemed to be having a low score. If the company considers these factors, the consumer will be influenced more towards the brand.

- The problematic factors like battery, display, keypad, audio and memory according to our study made the consumer's level of satisfactory to be low. So the companies must take a vigorous measure to rectify the problems especially to concentrate more on the battery and memory problems.

\section{CONCLUSION}

This study was conducted to increase our current understanding of the mobile phone market in general and analyze consumer's decision making in particular. The study attempted to cast light on the brand preference of the customers. This study has necessitated the Nokia Company must introduce more features which will be comparatively cheaper than their competitors. The Nokia must attract the consumers by providing many promotional strategies to maintain a long run market for their product. The Nokia must persuade and convince the customers by putting forth a confidence that their brand is non-problematic.

\section{REFERENCES:}

\section{BOOKS}

1. Philip Kolter - "Marketing Management."

2. Nilgel Hill \& Jim Alexander - "Handbook for Measuring Customer Satisfaction and loyalty." 


\section{MAGAZINES \& NEWS PAPER}

1. Indu.P, and Vivek Gupta, "Nokia's Business Strategy" - Case Folio, Dec.2005.

2. Thinakaran, The Daily News paper.

\section{WEBSITES}

1. hHp://www.nokia.com.

2. hHp://www.nokia.com/NOKIA_COM_1/About_Nokia/Sidebar_Teasers/Brochures/ NO KIA MANOR.pdf.

3. htlp://www.nokia.com/NOKIA_COM_1/About_Nokia/Sidebar_Teasers/Brochures/ TowardsTelecomms.pdf.

4. http://www.nokia.com/link? cid=EDITORIAL_3831

5. hHp://answers.com. 